\title{
Palmitoylation of the luteinizing hormone/human chorionic gonadotropin receptor regulates receptor interaction with the arrestin-mediated internalization pathway
}

\author{
Utpal M. Munshi, Helle Peegel and K. M. J. Menon \\ Departments of Biological Chemistry and Obstetrics/Gynecology, University of Michigan Medical School, Ann Arbor, MI, USA
}

The luteinizing hormone/human chorionic gonadotropin receptor (LH/hCGR) undergoes palmitoylation at cysteine residues 621 and 622 located in the carboxyl terminal tail of the receptor. This study examined the biological function of palmitoylation with respect to its effect on receptor internalization. Coexpression of wild-type (WT) or C621/ $622 \mathrm{G}$ mutant receptors with arrestin-2 increased receptor internalization in $293 \mathrm{~T}$ cells. Furthermore, measurements of rate enhancement upon overexpression of arrestin indicate that the palmitoylation deficient mutant receptor is more prone to utilizing the arrestin mediated internalization pathway than the WT receptor. Coexpression of G-protein-coupled receptor kinase 4 (GRK4) with wild type receptor resulted in an increase in internalization, while coexpression with the mutant receptor did not result in further enhancement of internalization. Additionally, $293 \mathrm{~T}$ cells expressing mutant receptor were responsive to hCG with respect to production of inositol phosphates. Taken together, these results suggest that the palmitoylation state of the receptor governs internalization by regulating the accessibility of the receptor to the arrestin-mediated internalization pathway.

Keywords: arrestin; GRK; internalization; LH/hCGR; palmitoylation.
Luteinizing hormone (LH) and its placental counterpart, human chorionic gonadotropin (hCG), bind to their receptor (LH/hCGR) in gonadal tissues, resulting in the increased production of cAMP and subsequent steroidogenesis [1]. LH/hCGR is a member of the G-proteincoupled receptor (GPCR) family. These receptors contain an N-terminal extracellular domain, seven transmembrane domains, and a C-terminal cytoplasmic tail $[2,3]$.

LH/hCGR is palmitoylated at cysteine residues 621 and 622 [4]. While palmitoylation of GPCRs is well conserved, its biological role varies from one member of the family to another [5-8]. For example, palmitoylation deficient mutants of the $\beta_{2}$ adrenergic receptor $\left(\beta_{2} \mathrm{AR}\right)$ exhibit a decreased ability to activate adenylate cyclase $[5,9]$ while corresponding mutants of the LH/hCGR retain the ability to mediate activation of this pathway $[4,10]$. Furthermore, palmitoylation has been shown to produce varying effects on receptor turnover $[4,11,12]$.

\footnotetext{
Correspondence to K. M. J. Menon, 6428 Medical Sciences Building I, 1301 Catherine Street, Ann Arbor, MI 48109-0617, USA.

Fax: + 1734936 8617, Tel.: + 1734764 8142,

E-mail: kmjmenon@umich.edu

Abbreviations: $\beta_{2} \mathrm{AR}, \beta_{2}$ adrenergic receptor; cAMP, adenosine 3',5'-cyclic monophosphate; ER, endoplasmic reticulum; GPCR, G-protein-coupled receptor; GRK, G-protein coupled receptor kinase; hCG, human chorionic gonadotropin; LH, luteinizing hormone; PMA, $4 \beta$-phorbol 12-myristate 13-acetate; WT, wild-type.

(Received 13 November 2000, revised 21 December 2000, accepted 18 January 2001)
}

Our previous studies showed that mutagenesis of palmitoylation sites has no effect on the ability to stimulate cyclic AMP production, but enhanced the rate of ligand-induced receptor internalization [4,10]. The present study examines the mechanism by which palmitoylation of the receptor affects internalization of the ligand-receptor complex. Specifically, we examined the interaction of the WT and palmitoylation deficient mutant receptor with arrestin, a component of the cell's endocytotic machinery [13-16]. Additionally, the role of palmitoylation on the receptor's ability to undergo G-protein coupled receptor kinase (GRK) stimulated internalization was examined, as GRKs are generally believed to play a role in hormone-induced phosphorylation of GPCRs and subsequent internalization [13-16]. The role of palmitoylation on the receptor's ability to undergo phosphorylation was also examined, as arrestin is believed to preferentially bind the phosphorylated form of GPCRs $[13,14]$.

In addition to stimulation of cyclic AMP production, LH is also able to stimulate phosphotidylinositol hydrolysis [17,18]. Activation of downstream kinases stimulated by this pathway could lead to receptor phosphorylation [19-21]. To further delineate the role of palmitoylation in receptor function, the activation of the phosphotidylinositol hydrolysis signaling pathway in response to hCG was measured in cells expressing WT or mutant receptor.

The results presented in this study show that a lack of palmitate at cysteine residues 621 and 622 renders the receptor more susceptible to arrestin-mediated internalization. Based on these results it is proposed that depalmitoylation might be an integral part of the mechanism by which the $\mathrm{LH} / \mathrm{hCG}$ receptor is internalized. 


\section{EXPERIMENTAL PROCEDURES}

\section{Materials}

Human chorionic gonadotropin (CR-127) was a gift from the Center for Population Research, NICHD, National Institutes of Health. $\mathrm{Na}^{125} \mathrm{I}$ was purchased from ICN. Human embryonic kidney cells (293T cells) expressing the large $\mathrm{T}$ antigen were a gift from G. P. Nolan, Stanford University. 293 cells were purchased from American Tissue Culture Collection. hCG for nonspecific binding was purchased from Sigma. All cell culture media was purchased from Gibco BRL. Fura-2 AM was purchased from Molecular Probes. $m y o\left[{ }^{3} \mathrm{H}\right]$ inositol, the ECL detection system, and secondary antibody to anti-GRK4 were purchased from Amersham Pharmacia. $\mathrm{LiCl}$ was purchased from Mallinckrodt Laboratories. AG 1-X8 formate resin and nitrocellulose membrane were purchased from Bio-Rad Laboratories. cDNAs for arrestin 2, 3, and (319-418) arrestin-2 were kindly provided by J. L. Benovic, Thomas Jefferson University. cDNAs for GRKs 2, 4 and 6 were kindly provided as a gift by R. Lefkowitz, Duke University. Primary antibody to arrestin-2 and GRK4, as well as secondary antibody to antiarrestin-2 were purchased from Santa Cruz Biotechnology, Inc. pCMV4 plasmid was a gift from D. Russell, University of Texas Southern Medical Center. All reagents used for molecular and cell biology were purchased in a suitably purified form. Mutant receptor cDNA was prepared as described previously $[4,10]$.

\section{Cell culture and transfection}

Experiments were performed as described previously using 293 or 293 T cells [4]. 293T cells were grown in DMEM containing $4500 \mathrm{mg} \cdot \mathrm{L}^{-1}$ glucose, $50 \mu \mathrm{g} \cdot \mathrm{mL}^{-1}$ gentamycin, $9 \mathrm{U} \cdot \mathrm{mL}^{-1}$ nystatin, $10 \mathrm{~mm}$ Hepes, and $10 \%$ fetal bovine serum at $37{ }^{\circ} \mathrm{C}$ in a humidified atmosphere containing $5 \% \mathrm{CO}_{2}$. Cells in exponential growth were plated 5-9 h before transfection at cell densities of $5-6 \times 10^{6}$ cells per $100 \mathrm{~mm}$ plate for inositol phosphate studies and $2-3 \times 10^{6}$ cells per $100-\mathrm{mm}$ plate for internalization studies. $293 \mathrm{~T}$ cells were transiently transfected using the calcium phosphate coprecipitation method. Stable transfections were performed in a similar manner to transient transfections, utilizing (geneticin) G418 for selection.

\footnotetext{
${ }^{125} \mathrm{I}$-Labelled hCG binding assay

All ${ }^{125}$ I-labelled hCG binding assays were performed as described previously [4] using a saturating concentration of ${ }^{125}$ I-labelled hCG. Briefly, cells were incubated with a saturating concentration (100 or $\left.120 \mathrm{ng} \cdot \mathrm{mL}^{-1}\right)$ of $\mathrm{hCG}$ at $4{ }^{\circ} \mathrm{C}$ or $37{ }^{\circ} \mathrm{C}$ for $30 \mathrm{~min}$ with or without a 1000 -fold excess of cold hCG to determine nonspecific binding. The cells were then washed twice at $4{ }^{\circ} \mathrm{C}$ with Waymouth's media. The radioactivity remaining with the cell pellet was then counted in a Gamma Trac $1290 \gamma$-counter (Tm Analytic). Specific binding was determined by subtracting nonspecific binding from total binding.
}

\section{Receptor-mediated ${ }^{125}$ I-hCG internalization assay}

The assays were performed as previously described [4,22] with slight modification. Transiently transfected 293T cells $\left(2-3 \times 10^{6}\right)$ were harvested with $\mathrm{NaCl} / \mathrm{P}_{\mathrm{i}}$-EDTA, washed, and resuspended in 3-8 mL of Waymouth's 752/1 medium as described in [22], the cell suspensions $(0.2 \mathrm{~mL})$ transferred into $12 \times 75 \mathrm{~mm}$ tubes, and incubated with a $100-\mathrm{ng} \cdot \mathrm{mL}^{-1}$ saturating concentration of ${ }^{125} \mathrm{I}$-labelled hCG at $37{ }^{\circ} \mathrm{C}$ for the time periods specified. Cells were incubated in the presence of a 1000-fold excess of unlabeled hCG to measure nonspecific binding. The reaction was stopped by the addition of $1.5 \mathrm{~mL}$ of Waymouth MB752/1 $\left(4^{\circ} \mathrm{C}\right)$ medium. After vortexing, the tubes were centrifuged at $4{ }^{\circ} \mathrm{C}$ at $1000 \mathrm{~g}$ for $5 \mathrm{~min}$. The supernatant was aspirated and the cells washed again. Following the second wash, the cells were incubated twice at $4{ }^{\circ} \mathrm{C}$ with $0.5 \mathrm{~mL}$ acid buffer $(150 \mathrm{~mm} \mathrm{NaCl}, 50 \mathrm{~mm}$ glycine, $\mathrm{pH} 3.0$ ) for $5 \mathrm{~min}$ to remove the surface bound ${ }_{125}$ I-labelled hCG. Previous studies have shown that greater than $90 \%$ of the surface bound hormone is removed by this procedure [4]. After each incubation, the cells were centrifuged at $4{ }^{\circ} \mathrm{C}$ at $2000 \mathrm{~g}$ for $5 \mathrm{~min}$. The $\left[{ }^{125} \mathrm{I}\right]$ in the pellets and acid washes was counted in a Gamma Trac $1290 \gamma$ counter (Tm Analytic). The radioactivity associated with the pellet represents the internalized receptor bound ligand, while radioactivity released by acid wash represents surface bound ligand.

\section{Determination of the internalization rate constant}

The first order rate constant of internalization was calculated as described previously [22]; the extent of internalization at $37{ }^{\circ} \mathrm{C}$ of ${ }^{125} \mathrm{I}$-labelled hCG was measured after $0-30 \mathrm{~min}$ of ${ }^{125} \mathrm{I}$-labelled $\mathrm{hCG}$ exposure. The rate constant was calculated from the equation $k t=2.3 \mathrm{log}$ (surface bound + internalized/surface bound), where $k$ is the first-order rate constant $\left(\mathrm{min}^{-1}\right)$, and $t=$ time (min) [22].

\section{Western blot analysis}

Firstly, 2.4-2.5 × $10^{6} 293 \mathrm{~T}$ cells were plated and transiently transfected in a $100 \mathrm{~mm}$ tissue culture dish as described above. Approximately $60 \mathrm{~h}$ after transfection, the cells were harvested in $\mathrm{NaCl} / \mathrm{P}_{\mathrm{i}}$-EDTA and subsequently lysed in $\mathrm{NaCl} / \mathrm{P}_{\mathrm{i}} 1 \% \mathrm{Tx}-100$. After allowing lysis to occur for $20 \mathrm{~min}$ on ice, cell lysate was centrifuged for $30 \mathrm{~min}$ at approximately $8{ }^{\circ} \mathrm{C}$ at $100000 \mathrm{~g}$. An aliquot of the supernatant was subsequently run on an SDS/PAGE gel under denaturing and reducing conditions. After separation on the gel, proteins were transferred to a nitrocellulose membrane. Antibody incubations were carried out as per the manufacturer's instructions, with a $1: 500$ dilution of goat anti-(arrestin-2) Ig and rabbit anti-GRK4 Ig, and a $1: 2500$ and $1: 5000$ dilution of horse radish peroxidase linked anti-goat and anti-rabbit Ig, respectively. Protein detection was performed using the ECL detection system (Amersham Pharmacia). 


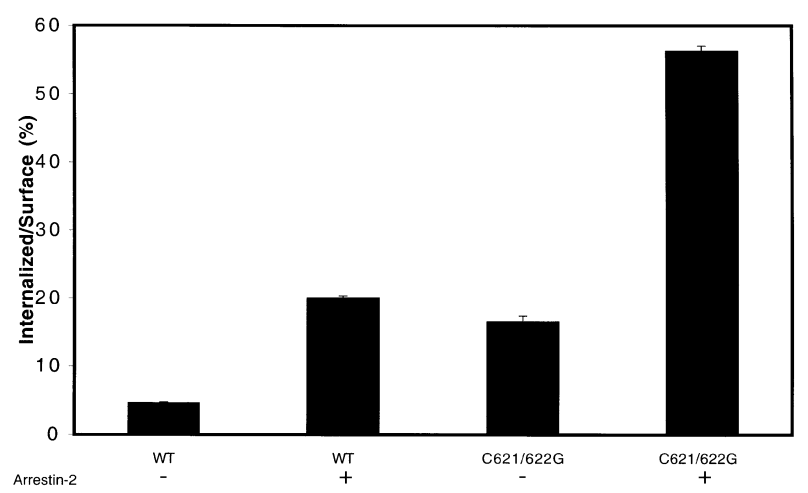

Fig. 1. Internalized ${ }^{125}$ I-labelled hCG as a percentage of surface bound ${ }^{125} \mathrm{I}$-labelled hCG in transiently transfected $293 \mathrm{~T}$ cells expressing WT or C621/622G receptor with, or without, arrestin-2. $293 \mathrm{~T}$ cells $\left(2.2 \times 10^{6}\right)$ were transiently transfected as described in Experimental procedures with $2.0 \mu \mathrm{g}$ of WT cDNA, or $6.0 \mu \mathrm{g}$ of C621/622G cDNA in the presence, or absence, of $6.0 \mu \mathrm{g}$ of arrestin-2 cDNA. Empty pCMV4 vector was also transfected into cells to equalize the mass of DNA used in all plates. Approximately $60 \mathrm{~h}$ after transfection, the cells were harvested and the internalization assays were performed as described in Experimental procedures. Internalization was measured after $20 \mathrm{~min}$ of exposure to $100 \mathrm{ng} \cdot \mathrm{mL}^{-1}{ }^{125} \mathrm{I}-$ labelled hCG at $37^{\circ} \mathrm{C}$. Data $=\%$ internalized ${ }^{125} \mathrm{I}$-labelled hCG/ surface bound ${ }^{125}$ I-labelled hCG $(\%) \pm$ SEM.

\section{[ $\left.{ }^{32} \mathrm{P}\right]$ Labeling of transfected cells used for receptor purification}

Approximately $60 \mathrm{~h}$ after transfection of $2-3 \times 10^{6} 293 \mathrm{~T}$ cells, the DMEM medium was removed and replaced with $\mathrm{P}_{\mathrm{i}}$-free medium containing $100 \mu \mathrm{Ci} \cdot \mathrm{mL}^{-1}$ of $\left[{ }^{32} \mathrm{P}\right]$ orthophosphate. The cells were then incubated at $37^{\circ} \mathrm{C}$ for $3 \mathrm{~h}$; $500 \mathrm{~nm} 4 \beta$-phorbol 12-myristate 13-acetate (PMA) was then added to the experimental plates and incubation extended for another hour.

\section{Purification of LH/hCG receptor using affi-gel chromatography}

$\mathrm{LH} / \mathrm{hCG}$ receptor was purified as described previously by hCG affi-gel chromatography [4]. After incubation with $\left.{ }^{32} \mathrm{P}\right]$ orthophosphate, cultures were placed on ice and washed with phosphate buffered saline $\left(\mathrm{NaCl} / \mathrm{P}_{\mathrm{i}}\right)$. The cells were harvested and washed with buffer $\mathrm{A}\left(\mathrm{NaCl} / \mathrm{P}_{\mathrm{i}}\right)$ supplemented with protease inhibitors (5 mM EDTA, $1 \mathrm{~mm}$ phenylmethanesulfonyl fluoride, $1 \mathrm{~mm}$ benzamidine, $1 \mathrm{~mm}$ $N$-ethylmaleamide, $2 \mu \mathrm{M}$ leupeptin, and $2 \mu \mathrm{M}$ trans-epoxysuccinyl-L-leucylamido-(4-guanidino)butane (E64), and phosphatase inhibitors (100 nM okadaic acid, $200 \mathrm{~nm}$ microcystin-LR, $100 \mu \mathrm{M}$ orthovanadate, and $10 \mathrm{~mm} \mathrm{NaF}$ ). The cell pellets were solubilized with buffer B $(0.15 \mathrm{M}$ $\mathrm{NaCl}$ and $20 \mathrm{~mm}$ Hepes, $\mathrm{pH}$ 7.4) containing $0.5 \%$ Nonidet P-40, 20\% glycerol, and the protease and phosphatase inhibitors present in buffer A. The supernatants were applied to affi-Gel covalently linked to highly purified hCG, and the suspension mixed end-over-end at $4{ }^{\circ} \mathrm{C}$ for $16 \mathrm{~h}$. The gel was washed several times and the receptor eluted with sample buffer C (2\% SDS, $10 \%$ glycerol, $20 \mathrm{~mm}$ EGTA, $0.5 \mathrm{mg} \cdot \mathrm{mL}^{-1}$ bromphenol blue and
$62.5 \mathrm{~mm}$ Tris, $\mathrm{pH} 6.8$ ) containing the protease and phosphatase inhibitors contained in buffer A.

\section{SDS/PAGE autoradiography}

The purified receptor was subjected to SDS/PAGE on a $7.5 \%$ acrylamide gel under reducing conditions $(0.05 \mathrm{M}$ dithiothreitol, 5\% 2-mercaptoethanol). The gels were then dried at $80{ }^{\circ} \mathrm{C}$ and exposed to Kodak X-Omat AR film for approximately $17 \mathrm{~h}$.

\section{$\mathrm{Ca}^{2+}$ measurements}

Assays were performed using a slight modification of the procedure described by Liao et al. [23]. Stably transfected 293 cells were labeled with $20 \mu \mathrm{M}$ Fura-2 AM at $37^{\circ} \mathrm{C}$ for $30 \mathrm{~min}$. After three washes with assay buffer $(140 \mathrm{~mm}$ $\mathrm{NaCl}, 5 \mathrm{~mm} \mathrm{KCl}, 1 \mathrm{~mm} \mathrm{MgCl}_{2}, 1.8 \mathrm{~mm} \mathrm{CaCl}, 10 \mathrm{~mm}$ dextrose, $0.1 \%$ BSA, and $15 \mathrm{~mm}$ Hepes, $\mathrm{pH} 7.4$ ), the cells were resuspended at a concentration of $1 \times$ $10^{6}$ cells $\cdot \mathrm{mL}^{-1}$, the cells placed in a SLM 8000 spectrophotometer (SLM-Aminco) and maintained at a temperature of $37{ }^{\circ} \mathrm{C}$. Fluorescence was monitored with an excitation wavelength of $340 \mathrm{~nm}$ and an emission wavelength of $510 \mathrm{~nm}$ in the absence and presence of $1 \mu \mathrm{g} \cdot \mathrm{mL}^{-1}$ CR-127 hCG. EDTA was added to a final concentration of $13 \mathrm{~mm}$ prior to hormone exposure.

\section{Inositol phosphate assays}

Assays were performed using a slight modification of the procedure described by Berridge et al. [24]. Briefly, transiently transfected $293 \mathrm{~T}$ cells $\left(5 \times 10^{6}\right)$ were labeled at $37{ }^{\circ} \mathrm{C}$ for $48 \mathrm{~h}$ with $75 \mu \mathrm{Ci}\left[{ }^{3} \mathrm{H}\right] m y o$-inositol. The cells were then harvested in $\mathrm{NaCl} / \mathrm{P}_{\mathrm{i}}$-EDTA $(1 \mathrm{mM})$, and resuspended in assay buffer $(142 \mathrm{~mm} \mathrm{NaCl}, 30 \mathrm{~mm}$ Hepes, $5.6 \mathrm{~mm} \mathrm{KCl}, 3.6 \mathrm{~mm} \mathrm{NaHCO}_{3}, 2.2 \mathrm{~mm} \mathrm{CaCl}_{2}$, $1.0 \mathrm{mM} \mathrm{MgCl} 2,1 \mathrm{mg} \cdot \mathrm{mL}^{-1}$ D-glucose, $15 \mathrm{~mm} \mathrm{LiCl}$ adjusted to $\mathrm{pH}$ 7.4). The cells were incubated in this buffer at $37{ }^{\circ} \mathrm{C}$ for at least $15 \mathrm{~min}$ prior to stimulation with hormone in a total volume of $0.5 \mathrm{~mL}$ per tube. After exposure of cells to varying concentrations of hormone at $37^{\circ} \mathrm{C}$ for $40 \mathrm{~min}$, the cells were immediately placed on ice, and $0.5 \mathrm{~mL}$ of $20 \%$ trichloroacetic acid was added. The cells were then vortexed and placed on ice for an additional $15 \mathrm{~min}$. Following centrifugation at $2000 \mathrm{~g}$, the supernatant was transferred to new tubes and washed five times with $2 \mathrm{~mL}$ of $\mathrm{dH}_{2} \mathrm{O}$ saturated ether. The $\mathrm{pH}$ was adjusted to $>6.0$ using $1 \mathrm{M} \mathrm{NaHCO}_{3}$, and $1.7 \mathrm{~mL}$ of $\mathrm{H}_{2} \mathrm{O}$ was added to each tube. Subsequently, $0.5 \mathrm{~mL}$ of an AG 1-X8 formate resin slurry was added to each tube. After vortexing, the samples were placed at $4{ }^{\circ} \mathrm{C}$ overnight. The following day, the samples were vortexed again, the supernatant was aspirated, and the resin was washed five times with $2.5 \mathrm{~mL}$ of $5 \mathrm{~mm}$ myo-inositol. The resin was then washed with $1 \mathrm{~mL}$ of an elution buffer $(0.1 \mathrm{~m}$ formic acid, $1.2 \mathrm{M}$ ammonium formate), vortexed, and incubated for $10 \mathrm{~min}$ at room temperature, and centrifuged. An aliquot of the supernatant was examined for $\left[{ }^{3} \mathrm{H}\right]$ inositol phosphates using a Beckman liquid scintillation counter. 


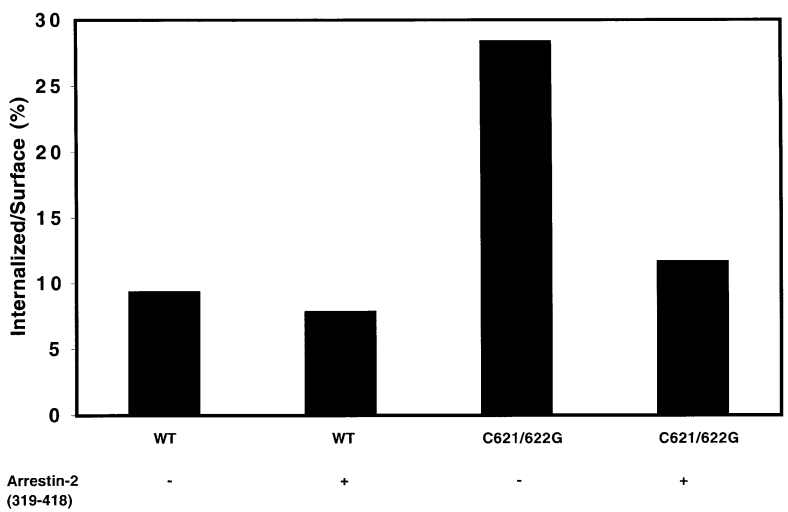

Fig. 2. Internalized ${ }^{125} \mathrm{I}$-labelled hCG as a percentage of surface bound ${ }^{125}$ I-labelled hCG in transiently transfected $293 \mathrm{~T}$ cells expressing WT or C621/622G receptor with or without (319-418) arrestin-2. 293T cells $\left(2.2 \times 10^{6}\right)$ were transiently transfected as described in Experimental procedures with $1.68 \mu \mathrm{g}$ of WT cDNA, or $4.40 \mu \mathrm{g}$ of C621/622G cDNA, with, or without, $6.71 \mu \mathrm{g}$ of (319-418) arrestin-2 cDNA. Empty pCMV4 vector was also transfected into cells to equalize the mass of DNA used in all plates. Approximately $60 \mathrm{~h}$ after transfection, the cells were harvested and the internalization assays performed as described in Experimental procedures. Internalization was measured after $20 \mathrm{~min}$ of exposure to $100 \mathrm{ng} \cdot \mathrm{mL}^{-1}$ ${ }^{125} \mathrm{I}$-labelled hCG at $37^{\circ} \mathrm{C}$. The data shown are the results of one of two experiments conducted and show internalized ${ }^{125} \mathrm{I}$-labelled hCG/ surface bound ${ }^{125}$ I-labelled hCG $(\%)$.

\section{RES U LT S}

\section{Effect of arrestin-2 on internalization of palmitoylation deficient mutant receptor}

We determined whether the rate of internalization of the palmitoylation deficient mutant receptor $[4,10]$ is affected by overexpression with arrestin. To test this, 293T cells were transiently transfected with WT or mutant receptor cDNA in the presence, or absence, of a second vector encoding arrestin-2. Cells were harvested $60 \mathrm{~h}$ after transfection and internalization was measured at $37^{\circ} \mathrm{C}$ after $20 \mathrm{~min}$ of exposure to ${ }^{125}$ I-labelled hCG. The internalization of WT and C621/622G LH/hCGR increased upon coexpression with arrestin-2 (Fig. 1), suggesting that the palmitoylation deficient mutant receptor can be internalized by an arrestin-mediated pathway.

To further substantiate that the palmitoylation deficient receptor is internalized via an arrestin-mediated mechanism, 293T cells were transiently transfected with cDNA encoding WT or mutant receptor and a truncated, dominant negative form of arrestin-2 (amino-acid residues 319-418) that retains the ability to bind clathrin, but is unable to bind the phosphorylated receptor [16]. Internalization of the C621/622G mutant receptor was inhibited when coexpressed with the dominant negative form of arrestin-2 (Fig. 2). A $62.5 \pm 3.5 \%$ (SEM of two independent experiments) decrease in internalization of the mutant receptor was seen when coexpressed with (319-418) arrestin-2 compared to a $20.5 \pm 4.5 \%$ (SEM of two independent experiments) decrease for the WT control. The inhibition of mutant receptor internalization by the dominant negative arrestin-2 further shows that the palmitoylation deficient mutant
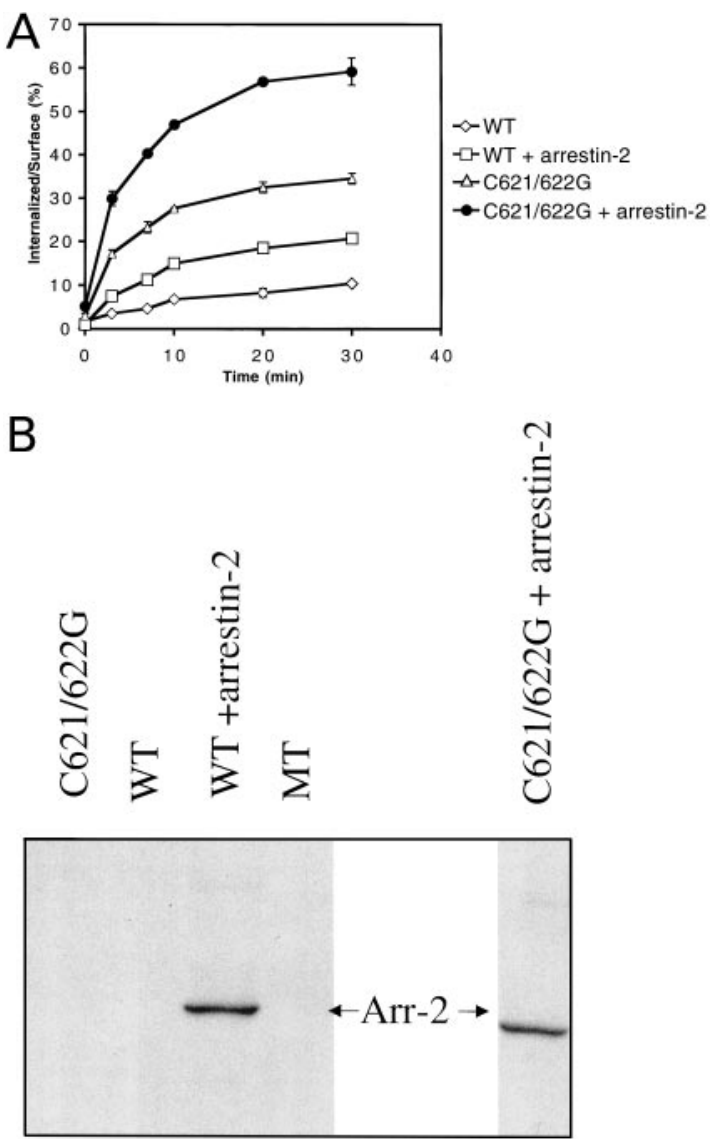

Fig. 3. Time course and rate of ${ }^{125} \mathrm{I}$-labelled $\mathrm{hCG}$ internalization in cells expressing WT or C621/622G receptor with or without arrestin-2. 293T cells $\left(2.4-2.5 \times 10^{6}\right)$ were transiently transfected as described in Experimental procedures with $2.0 \mu \mathrm{g}$ of WT cDNA, or $6.0 \mu \mathrm{g}$ of C621/622G cDNA with or without $6.0 \mu \mathrm{g}$ of arrestin-2 cDNA. Empty pCMV4 vector was also transfected into cells to equalize the mass of DNA used in all plates. Approximately $60 \mathrm{~h}$ after transfection, cells were harvested and internalization assays performed as described in Experimental procedures. Internalized ${ }^{125}$ I-labelled hCG was measured, as described in Experimental procedures, from 0 to $30 \mathrm{~min}$ of exposure to $100 \mathrm{ng} \cdot \mathrm{mL}^{-1125}$ I-labelled hCG at $37^{\circ} \mathrm{C}$ and is expressed as a percentage of surface-bound ${ }^{125} \mathrm{I}$-labelled hCG in cells expressing WT or mutant receptor with or without (A) arrestin-2. The data are representative of four independent experiments \pm SEM. (B) Western blot showing relative expression of arrestin-2 in cells transfected with WT or C621/622G receptor cDNA with or without cDNA expressing arrestin-2 as described for (A) loaded with approximately $11.5 \mu \mathrm{g}$ of total protein per lane, except for MT (mock transfect) lane, where approximately $7.5 \mu \mathrm{g}$ of total protein was loaded.

receptor internalization occurs in large part through an arrestin-mediated pathway.

To examine more closely the influence of the palmitoylation state of the receptor on interaction with the arrestinmediated internalization pathway, the time course of WT or mutant receptor internalization in the absence or presence of coexpressed arrestin-2 was examined. Cells (293T) were transiently transfected with the appropriate cDNAs, harvested $60 \mathrm{~h}$ later, and the time course of internalization was determined. The percent internalization of WT and mutant 
Table 1. Effects of arrestin-2 overexpression on WT and mutant receptor internalization. The data presented are the average of four independent experiments.

\begin{tabular}{lll}
\hline & $\begin{array}{l}\text { First order rate constant } \\
\text { of }{ }^{125} \text { I-labelled hCG } \\
\text { internalization } \\
\times 10^{-3}\left(\mathrm{~min}^{-1}\right) \pm \text { SEM }\end{array}$ & $\begin{array}{l}\text { Rate } \\
\text { enhancement }\end{array}$ \\
$\begin{array}{l}\text { Receptor } \\
\text { constructs }\end{array}$ & $2.01 \pm 0.30$ & - \\
\hline WT & $4.49 \pm 0.66$ & 2.2 \\
WT + arrestin-2 & $5.18 \pm 1.23$ & - \\
C621/622G & $8.86 \pm 1.52$ & 1.7 \\
C621/622G + arrestin-2 & & \\
\hline
\end{tabular}

${ }^{a}$ Rate enhancement is the factor by which the rate constant increases in the presence of coexpressed arrestin-2 for each receptor construct.

receptor in the absence or presence of coexpressed arrestin-2 increased with time (Fig. 3A).

The first order rate constants of internalization were calculated from the data presented in Fig. $3 \mathrm{~A}$ and are summarized in Table 1. The results show that the rate constants of internalization were higher upon coexpression of arrestin-2 for both the WT and the mutant receptor. Interestingly, coexpression of arrestin- 2 along with the WT receptor resulted in a greater rate enhancement compared to that seen for the mutant receptor. This suggests that a lack of palmitoylation of the receptor renders it more susceptible to internalization via endogenous arrestin, such that overexpression of exogenous arrestin can not stimulate mutant receptor internalization as much as WT receptor internalization. LH/hCGR cell surface expression was measured by incubating cells with ${ }^{125}$ I-labelled hCG for 30 min at $4{ }^{\circ} \mathrm{C}$. Results indicated comparable cell surface receptor expression between WT and mutant receptor expressing cells (data not shown). Furthermore, arrestin-2 overexpression in cells expressing mutant receptor was slightly lower than in cells expressing WT receptor (Fig. 3B). Densitometric analysis showed that arrestin-2 overexpression in cells expressing the C621/622G receptor was approximately $80 \%$ of that in cells expressing the WT receptor (data not shown). However, in both cases, arrestin-2 was overexpressed at a high level, and therefore any differences in arrestin-2 overexpression are unlikely to contribute to the differences in rate enhancement.

\section{Effect of GRK4 on receptor internalization}

As arrestin is known to preferentially bind the phosphorylated form of GPCRs $[13,14]$, the time course of WT and palmitoylation deficient mutant receptor internalization in the absence, or presence, of coexpressed GRK4, which can promote agonist induced phosphorylation of the receptor [19], was examined. The internalization of the WT and the mutant receptors increased over time when coexpressed with GRK4 (Fig. 4A). The first order rate constants of internalization were calculated from the data presented in Fig. 4A and are summarized in Table 2. While the rate constant of internalization of the mutant receptor was not increased by GRK4 coexpression, the rate enhancement seen for the WT receptor was substantial.
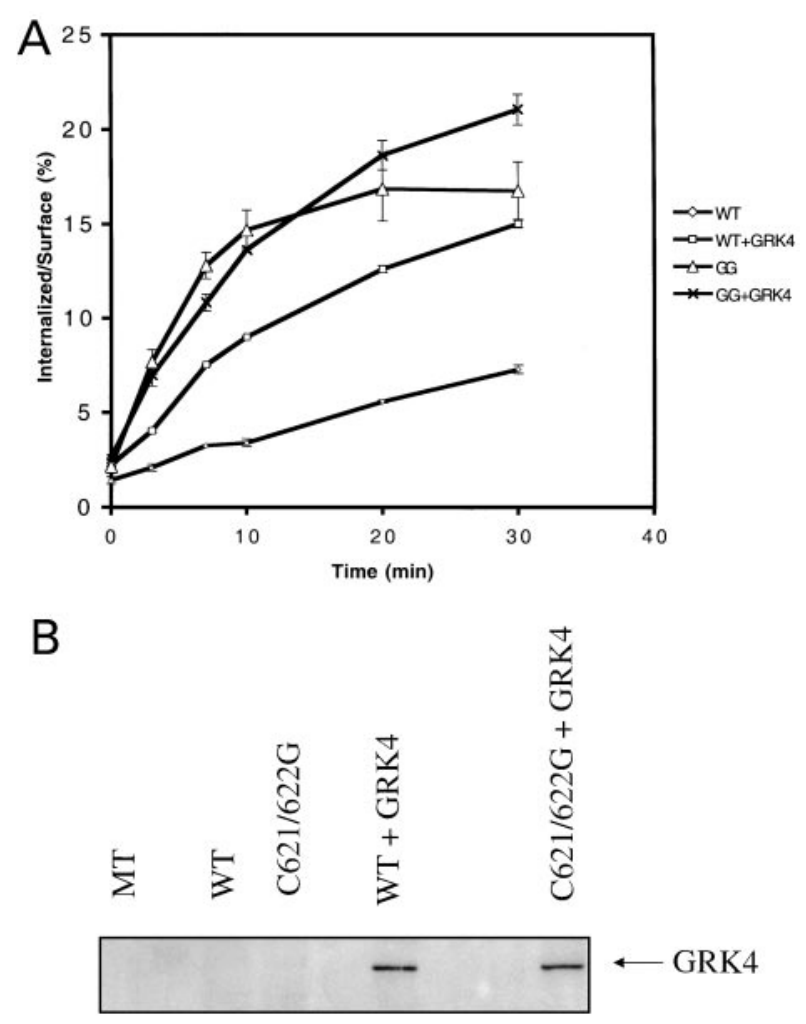

Fig. 4. Time course and rate of ${ }^{125} \mathrm{I}$-labelled hCG internalization in cells expressing WT or C621/622G receptor with or without GRK4. (A) $293 \mathrm{~T}$ cells $\left(2.4-2.5 \times 10^{6}\right)$ were transiently transfected as described in Experimental procedures with $2.0 \mu \mathrm{g}$ of WT cDNA, or $6.0 \mu \mathrm{g}$ of $\mathrm{C} 621 / 622 \mathrm{G}$ cDNA in the presence, or absence, of $6.0 \mu \mathrm{g}$ GRK4 cDNA. Empty pCMV4 vector was also transfected into cells to equalize the mass of DNA used in all plates. Approximately $60 \mathrm{~h}$ after transfection, the cells were harvested and internalization assays performed as described in Experimental procedures. Internalized ${ }^{125}$ I-labelled hCG was measured as described in Experimental procedures at $37^{\circ} \mathrm{C}$ after exposure from 0 to $30 \mathrm{~min}$ to $100 \mathrm{ng} \cdot \mathrm{mL}^{-1}$

${ }^{125} \mathrm{I}$-labelled $\mathrm{hCG}$ and expressed as a percentage of surface-bound

${ }^{125}$ I-labelled hCG in cells expressing WT or mutant receptor with, or without, GRK4. The data are representative of five independent experiments \pm SEM. (B) Western blot showing relative expression of GRK4 in cells transfected with WT or C621/622G receptor cDNA with or without cDNA expressing GRK4, as described in (A). Approximately $7.5 \mu \mathrm{g}$ of total protein was loaded in the WT and C621/622G lanes, $5 \mu \mathrm{g}$ of total protein in the MT (mock transfect) lane, and approximately $5.5 \mu \mathrm{g}$ of total protein in the WT + GRK4, and C621/ $622 \mathrm{G}+$ GRK4 lanes, respectively.

This suggests that a lack of palmitoylation renders the receptor less susceptible to stimulation of internalization by exogenous GRKs. LH/hCGR cell surface expression was measured by incubating cells with ${ }^{125}$ I-labelled hCG for $30 \mathrm{~min}$ at $4{ }^{\circ} \mathrm{C}$. Results indicated comparable receptor expression between WT and mutant receptor expressing cells (data not shown). Furthermore, GRK4 overexpression was comparable in cells expressing WT or mutant receptor (Fig. 4B). Densitometric analysis showed that GRK4 overexpression in cells expressing the C621/622G mutant receptor was approximately $90 \%$ of that in cells expressing the WT receptor (data not shown). This difference is too small to account for the large difference 
Table 2. Effects of GRK4 overexpression on WT and mutant receptor internalization. The data presented are the average of five independent experiments.

\begin{tabular}{|c|c|c|}
\hline $\begin{array}{l}\text { Receptor } \\
\text { constructs }\end{array}$ & $\begin{array}{l}\text { First order rate constant } \\
\text { of }{ }^{125} \text { I-labelled hCG } \\
\text { internalization } \\
\times 10^{-3}\left(\mathrm{~min}^{-1}\right) \pm \mathrm{SEM}\end{array}$ & $\begin{array}{l}\text { Rate } \\
\text { enhancement }^{\text {a }}\end{array}$ \\
\hline WT & $1.79 \pm 0.22$ & - \\
\hline $\mathrm{WT}+\mathrm{GRK} 4$ & $3.50 \pm 0.22$ & 2.0 \\
\hline C621/622G & $4.46 \pm 0.92$ & - \\
\hline C621/622G + GRK 4 & $4.97 \pm 0.62$ & 1.1 \\
\hline
\end{tabular}

${ }^{a}$ Rate enhancement is the factor by which the rate constant increases in the presence of coexpressed GRK4 for each receptor construct.

in rate enhancement seen upon GRK4 overexpression between cells expressing the WT and mutant forms of the receptor.

\section{Effect of PMA on receptor phosphorylation}

As the C-terminal portion of the receptor contains consensus phosphorylation sites for protein kinase $\mathrm{C}$ and protein kinase A [25], the ability of WT and palmitoylation deficient mutant receptors to undergo phosphorylation in

\section{LH/hCGR}

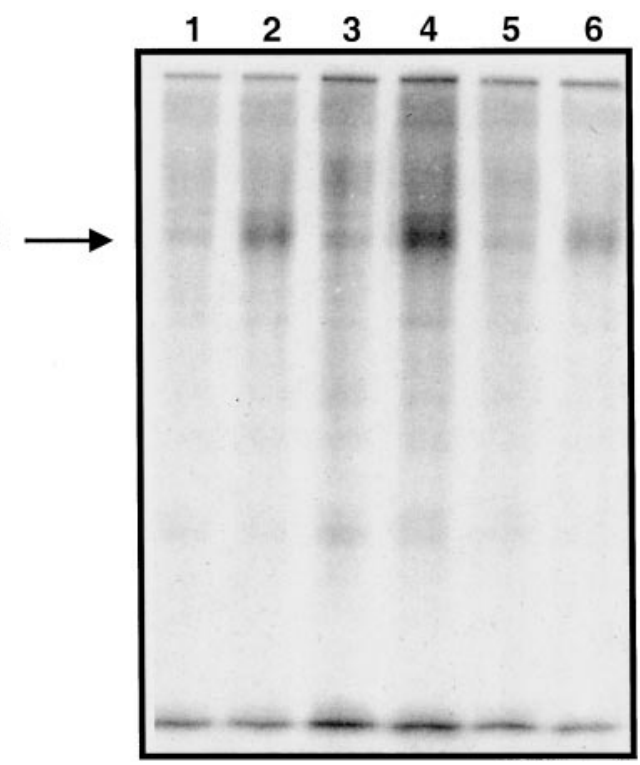

Fig. 5. PMA-stimulated phosphorylation of WT and palmitoylation deficient mutant receptors. Sixty hours after transient transfection of $2-3 \times 10^{6} 293 \mathrm{~T}$ with cDNA expressing WT, C621/622G, or C621/ $622 \mathrm{~S}$ cDNA, the cells were labeled with $100 \mu \mathrm{Ci} \cdot \mathrm{mL}^{-1}\left[{ }^{32} \mathrm{P}\right]$ orthophosphate for $3 \mathrm{~h}$ as described in Experimental procedures. The cells were then incubated with, or without, 500 nм PMA for $1 \mathrm{~h}$. The cells were harvested, and the LH/hCGR purified as described in Experimental procedures. The purified receptors were subjected to SDS/PAGE under reducing conditions, and the labeled phosphorylated receptor was visualized by autoradiography. An equivalent amount of eluate from the purification procedure was loaded into each lane. Lanes 1 and 2, C621/622G; lanes 3 and 4, C621/622S; Lanes 5 and 6, WT receptor; Lanes 1, 3, 5, without PMA; lanes 2,4, and 6 with PMA.
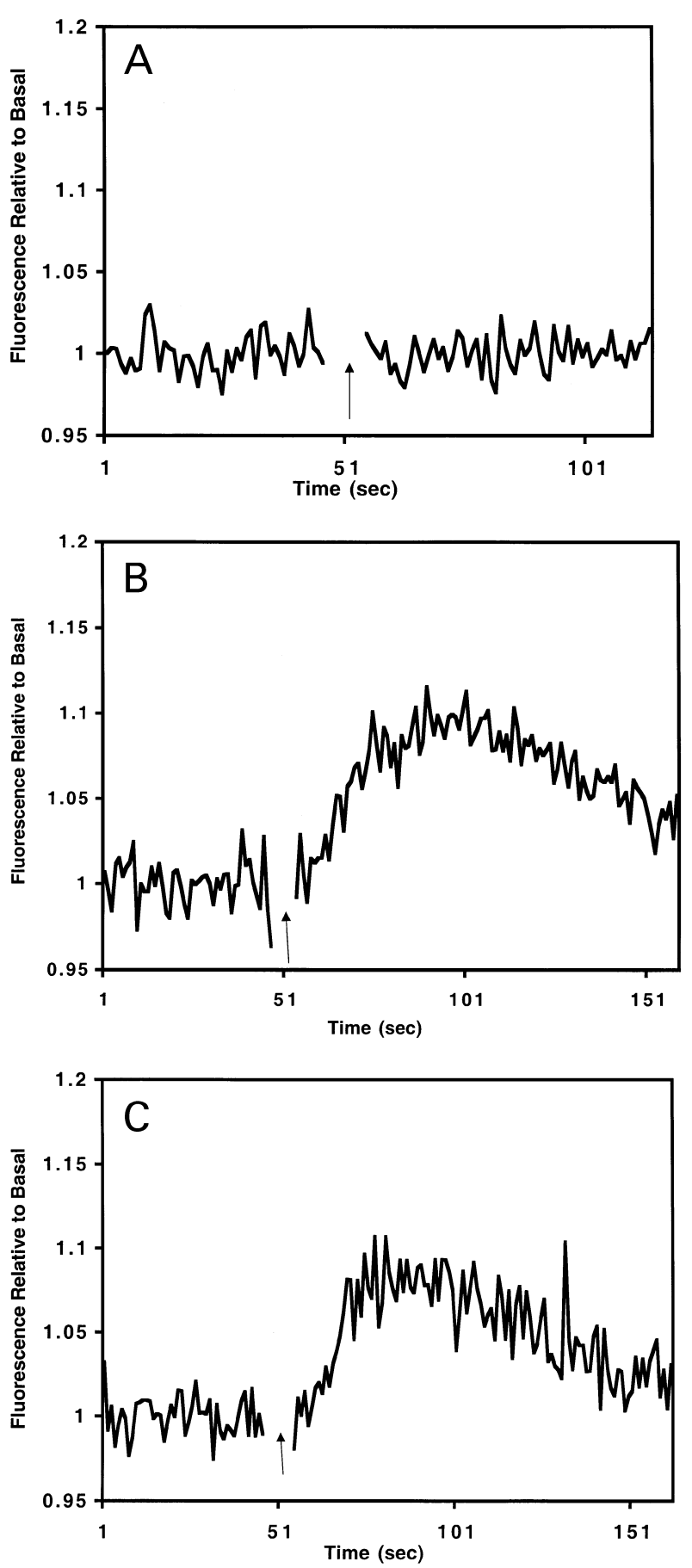

Fig. 6. Calcium release in stably transfected 293 cells expressing WT or palmitoylation deficient LH/hCG receptor. 293 cells stably transfected with pCMV4 expressing WT, or C621/622S mutant receptor were harvested and labeled with Fura 2-AM, as described in Experimental procedures; $2 \times 10^{6}$ cells were used per sample. Each plot shows the fold increase in fluorescence emission over baseline (fluorescence relative to basal) at $510 \mathrm{~nm}$. [fluorescence relative to basal vs. time (s) upon addition of $1 \mu \mathrm{g} \cdot \mathrm{mL}^{-1}$ hCG (arrow)] for cells expressing (A) no receptor, (B) WT receptor or (C) C621/622S receptor. Data are representative of two independent experiments. 


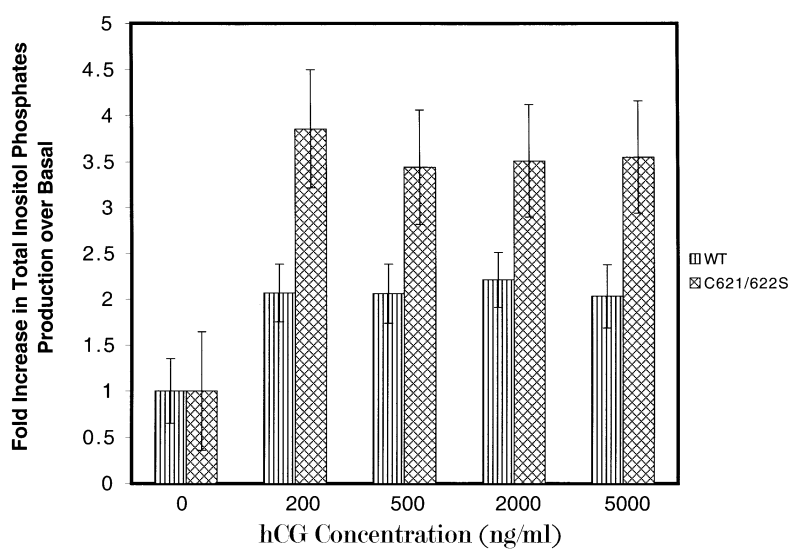

Fig. 7. Increase in total inositol phosphates production in transiently transfected 293T cells expressing WT or palmitoylation deficient LH/hCG Receptor. 293T cells $\left(5 \times 10^{6}\right)$ were transiently transfected with $3 \mu \mathrm{g}$ of WT cDNA or $12 \mu \mathrm{g}$ C621/622S mutant cDNA to give approximately equivalent receptor expression. Twelve hours later, the cells were labelled with $75 \mu \mathrm{Ci}$ of $\left[{ }^{3} \mathrm{H}\right]$ myo-inositol. Fortyeight hours after labeling, the cells were harvested and stimulated with 0 to $5000 \mathrm{ng} \cdot \mathrm{mL}^{-1} \mathrm{hCG}$ at $37^{\circ} \mathrm{C}$ for $40 \mathrm{~min}$. Total inositol phosphates were assayed as described in Experimental procedures. The increase in inositol phosphates production was calculated as the quotient of c.p.m. of $\left[{ }^{3} \mathrm{H}\right]$ inositol phosphates produced at a given hCG concentration/ c.p.m. of $\left[{ }^{3} \mathrm{H}\right]$ inositol phosphates produced at $[\mathrm{hCG}]=0$ for each cell type.

response to PMA or 8-bromo cAMP was examined. The transfected cells were labeled with $\left[{ }^{32} \mathrm{P}\right]$ orthophosphate for $3 \mathrm{~h}$. Subsequently, cells expressing WT, C621/622G, or C621/622S palmitoylation deficient mutant receptors were treated with 500 nM PMA for $1 \mathrm{~h}$. Controls were incubated in the absence of PMA. Following the incubation, the cells were harvested and solubilized. The LH/hCGR was purified by hCG-affigel chromatography, subjected to SDS/PAGE under reducing conditions, and the phosphorylated receptor was visualized by autoradiography, as described in Experimental procedures. The results show (Fig. 5) an increase in phosphorylation of both the WT and the mutant receptors upon PMA stimulation. Furthermore, both forms of the mutant receptor are more susceptible to PMA stimulated phosphorylation compared to the WT receptor. Densitometric analysis showed that PMA stimulated a 3.5-fold increase in C621/622G phosphorylation, 3.3-fold increase in C621/622S phosphorylation, and 1.8-fold increase of WT receptor phosphorylation (data not shown). 8-Bromo cAMP did not stimulate phosphorylation of the WT receptor to any appreciable extent (data not shown). These results suggest that the palmitoylation state may regulate the phosphorylation state of the $\mathrm{LH} / \mathrm{hCG}$ receptor, with the unpalmitoylated form of the receptor being more susceptible to phosphorylation.

\section{Effect of hCG on $\mathrm{Ca}^{2+}$ release}

To further examine the biological role of receptor palmitoylation, we examined the effect of palmitoylation on receptor signaling through the phospholipase $\mathrm{C}$ pathway. Specifically, the ability of the palmitoylation deficient mutant to mediate the hCG-induced production of inositol phosphates and $\mathrm{Ca}^{2+}$ flux from the ER to the cytoplasm was measured.

The release of $\mathrm{Ca}^{2+}$ from the ER into the cytosol upon hCG binding was detected by an increase in fluorescence emission at $510 \mathrm{~nm}$ in 293 cells stably transfected with WT or C621/622S mutant receptor cDNA that were loaded with the fluorescent calcium chelator, Fura- 2 AM. The results presented in Fig. 6A-C show the release of calcium from the ER into the cytosol in untransfected cells, cells transfected with WT, or C621/622S cDNA, respectively, upon addition of $1 \mu \mathrm{g} \cdot \mathrm{mL}^{-1}$ hCG. 293T cells transiently transfected with $\mathrm{C} 621 / 622 \mathrm{G}$ receptor cDNA also displayed $\mathrm{Ca}^{2+}$ release from the ER into the cytosol upon addition of $1 \mu \mathrm{g} \cdot \mathrm{mL}^{-1} \mathrm{hCG}$ (data not shown). These results show that the palmitoylation deficient mutant receptor retains the ability to mediate $\mathrm{Ca}^{2+}$ release from the ER into the cytosol.

\section{WT and palmitoylation deficient mutant receptor mediated activation of inositol phosphates production}

To further confirm that the WT and palmitoylation deficient mutant receptors mediate activation of the phospholipase $\mathrm{C}$ pathway, we measured the production of total inositol phosphates as a function of hCG concentration in 293T cells transiently expressing equal numbers of WT or C621/ $622 \mathrm{~S}$ mutant receptor. The results presented in Fig. 7 show that both the WT and the mutant receptor have the ability to mediate the activation of inositol phosphate production upon hCG binding.

\section{I S C U S S I O N}

As a continuation of earlier studies on $\mathrm{LH} / \mathrm{hCG}$ receptor palmitoylation $[4,10]$, the present study examined the effect of overexpression of various components of the cell's endocytotic machinery on WT and palmitoylation deficient mutant receptor internalization. Our results show that a lack of palmitoylation results in a higher rate of internalization, which is largely arrestin-2 dependent, while the internalization of the WT receptor appears to be largely resistant to dominant negative arrestin-2 inhibition. Additionally, coexpression of GRK4 increases WT receptor internalization, but has no effect on the internalization of the C621/ $622 \mathrm{G}$ receptor. Finally, we show that abrogation of palmitoylation does not eliminate the ability of the mutant receptor to activate the phospholipase $\mathrm{C}$ signaling pathway.

The basal rate of internalization of the mutant receptor was higher than the WT, but the WT receptor showed a greater rate of enhancement of internalization than the mutant upon overexpression of arrestin-2. This suggests that the mutant receptor preferentially uses endogenous arrestin for internalization compared to the WT receptor. The minimal effect of dominant negative arrestin- 2 on WT receptor internalization may be due to hindrance of the receptor-arrestin interaction by the two palmitate residues. This may result in the WT receptor using alternative pathways of internalization, such as the AP-2 mediated internalization pathway [26]. Taken together, these data suggest that a lack of palmitoylation confers on the receptor a greater ability to undergo arrestin-mediated internalization, while palmitoylation interferes with receptor-arrestin 
interaction and results in the use of alternative internalization pathways. As coexpression of arrestin-3 was able to promote a greater rate enhancement of the mutant receptor than arrestin-2 (data not shown), it is unlikely that the lower rate enhancement of the mutant receptor in the presence of arrestin-2 was due to the limiting nature of other cellular components required for internalization, such as clathrin and dynamin.

The lower rate enhancement of the mutant compared to the WT was also not due to differences in transfection efficiency (data not shown). It is expected that 293T cells endogenously express arrestin-2, as coexpression with (319-418) arrestin-2 inhibited mutant receptor internalization. Furthermore, it has been previously shown that arrestin-2 is expressed in 293 cells and may be ubiquitously expressed in tissues [27-30]. Along these lines, it was found that arrestin-2 was overexpressed in cells expressing the $\mathrm{C} 621 / 622 \mathrm{G}$ mutant receptor at levels comparable to that seen in cells expressing the WT receptor (Fig. 3B). Although there is a slight decrease in the level of overexpression of arrestin- 2 in the mutant receptor expressing cells, this decrease is not expected to have an effect on the rate of internalization. Furthermore, the rate of internalization of the WT receptor is comparable to the rate of the C621/622G mutant internalization only when arrestin-2 is overexpressed with the WT receptor (Table 1). Thus, the palmitoylation deficient receptor is more susceptible to interaction with the arrestin-mediated internalization pathway than the WT receptor.

The GRK family of kinases may play a role in hormoneinduced phosphorylation of GPCRs [13-16]. Overexpression of GRK4 resulted in an increase in the rate of internalization of the WT receptor, while there was no increase for the mutant receptor. Differences in GRK4 overexpression are unlikely to play a role in rate enhancement (Fig. 4B). Furthermore, the rate of internalization of the WT receptor is comparable to that of the C621/622G mutant receptor only when GRK4 was overexpressed in the presence of the WT receptor (Table 2). This suggests that a lack of palmitoylation facilitates internalization through promoting receptor phosphorylation. As GRKs probably stimulate internalization through phosphorylation of the C-terminus of the receptor $[13-16,19]$, it is possible that either the C-terminus is hyperphosphorylated in the unpalmitoylated mutant, and consequently GRK4 overexpression has little effect on internalization, or that a lack of palmitoylation inhibits GRK4 stimulated internalization through an unknown mechanism. The hypothesis that the unpalmitoylated receptor might be hyperphosphorylated is supported by the data presented in Fig. 5, which show that both unpalmitoylated forms of the receptor have a greater ability to undergo PMA-stimulated phosphorylation than the WT receptor.

Previous studies on the desensitization of the $\beta 2 \mathrm{AR}$ have shown that it proceeds through a depalmitoylated, hyperphosphorylated state [9,28,31-34]. Our finding that GRK4 overexpression had no effect on mutant receptor internalization would support the notion that the mutant receptor might exist in an hyperphosphorylated state that is more prone to arrestin-mediated internalization. In summary, the present study suggests that $\mathrm{LH} / \mathrm{hCG}$ receptor internalization might proceed through a depalmitoylated/hyperphosphorylated intermediate during prolonged exposure to hormone.

\section{A C K N O W LED GEMENTS}

We thank Dr Geneva Omann for the use of her 8000 SLM Spectrophotometer and advice on $\mathrm{Ca}^{2+}$ measurements, and Dr Anil Nair and Dr William Jourdian for their critical review of this manuscript. This work was funded by National Institutes of Health Grant HD-06656. U. M. M. is a predoctoral fellow supported by National Institutes of Health Training Grant PR5-T32 HD-07048.

\section{REFERE N CES}

1. Menon, K.M. \& Gunaga, K.P. (1974) Role of cyclic AMP in reproductive processes. Fertility Sterility 25, 732-750.

2. McFarland, K.C., Sprengel, R., Phillips, H.S., Kohler, M., Rosemblit, N., Nikolics, K., Segaloff, D.L. \& Seeburg, P.H. (1989) Lutropin-choriogonadotropin receptor: an unusual member of the G protein-coupled receptor family. Science. 245, 494-499.

3. Loosfelt, H., Misrahi, M., Atger, M., Salesse, R., Vu Hai-Luu Thi, M.T., Jolivet, A., Guiochon-Mantel, A., Sar, S., Jallal, B. \& Garnier, J. (1989) Cloning and sequencing of porcine LH-hCG receptor cDNA: variants lacking transmembrane domain. Science 245, 525-528.

4. Kawate, N. \& Menon, K.M. (1994) Palmitoylation of luteinizing hormone/human choriogonadotropin receptors in transfected cells. Abolition of palmitoylation by mutation of Cys-621 and Cys-622 residues in the cytoplasmic tail increases ligand-induced internalization of the receptor. J. Biol. Chem. 269, 30651-30658.

5. O’Dowd, B.F., Hnatowich, M., Caron, M.G., Lefkowitz, R.J. \& Bouvier, M. (1989) Palmitoylation of the human beta 2-adrenergic receptor. Mutation of Cys341 in the carboxyl tail leads to an uncoupled nonpalmitoylated form of the receptor. J. Biol. Chem. 264, 7564-7569.

6. Kennedy, M.E. \& Limbird, L.E. (1993) Mutations of the alpha 2A-adrenergic receptor that eliminate detectable palmitoylation do not perturb receptor-G-protein coupling. J. Biol. Chem. 268, 8003-8011.

7. Ng, G.Y., Mouillac, B., George, S.R., Caron, M., Dennis, M., Bouvier, M. \& O'Dowd, B.F. (1994) Desensitization, phosphorylation and palmitoylation of the human dopamine D1 receptor. Eur. J. Pharmacol. 267, 7-19.

8. Ng, G.Y., George, S.R., Zastawny, R.L., Caron, M., Bouvier, M., Dennis, M. \& O’Dowd, B.F. (1993) Human serotonin1B receptor expression in Sf9 cells: phosphorylation, palmitoylation, and adenylyl cyclase inhibition. Biochemistry 32, 11727-11733.

9. Moffett, S., Mouillac, B., Bonin, H. \& Bouvier, M. (1993) Altered phosphorylation and desensitization patterns of a human beta 2 -adrenergic receptor lacking the palmitoylated Cys341. EMBO J. 12, 349-356.

10. Kawate, N., Peegel, H. \& Menon, K.M. (1997) Role of palmitoylation of conserved cysteine residues of luteinizing hormone/human choriogonadotropin receptors in receptor downregulation. Mol. Cell. Endocrinol. 127, 211-219.

11. Tanaka, K., Nagayama, Y., Nishihara, E., Namba, H., Yamashita, S. \& Niwa, M. (1998) Palmitoylation of human thyrotropin receptor: slower intracellular trafficking of the palmitoylation-defective mutant. Endocrinology 139, 803-806.

12. Campbell, P.T., Hnatowich, M., O’Dowd, B.F., Caron, M.G., Lefkowitz, R.J. \& Hausdorff, W.P. (1991) Mutations of the human beta 2-adrenergic receptor that impair coupling to Gs interfere with receptor down-regulation but not sequestration. Mol. Pharmacol. 39, 192-198. 
13. Premont, R.T., Inglese, J. \& Lefkowitz, R.J. (1995) Protein kinases that phosphorylate activated $\mathrm{G}$ protein-coupled receptors. FASEB J. 9, 175-182.

14. Hausdorff, W.P., Caron, M.G. \& Lefkowitz, R.J. (1990) Turning off the signal: desensitization of beta-adrenergic receptor function [erratum appears in FASEB J. (1990) 4, 3049]. FASEB J. 4, 2881-2889.

15. Goodman, O.B. Jr, Krupnick, J.G., Santini, F., Gurevich, V.V., Penn, R.B., Gagnon, A.W., Keen, J.H. \& Benovic, J.L. (1996) Beta-arrestin acts as a clathrin adaptor in endocytosis of the beta2adrenergic receptor. Nature 383, 447-450.

16. Krupnick, J.G., Santini, F., Gagnon, A.W., Keen, J.H. \& Benovic, J.L. (1997) Modulation of the arrestin-clathrin interaction in cells. Characterization of beta-arrestin dominant-negative mutants. J. Biol. Chem. 272, 32507-32512.

17. Davis, J.S., Weakland, L.L., Farese, R.V. \& West, L.A. (1987) Luteinizing hormone increases inositol trisphosphate and cytosolic free $\mathrm{Ca}^{2+}$ in isolated bovine luteal cells. J. Biol. Chem. 262, 8515-8521.

18. Gudermann, T., Nichols, C., Levy, F.O., Birnbaumer, M. \& Birnbaumer, L. (1992) $\mathrm{Ca}^{2+}$ mobilization by the $\mathrm{LH}$ receptor expressed in Xenopus oocytes independent of $3^{\prime}, 5^{\prime}$-cyclic adenosine monophosphate formation: evidence for parallel activation of two signaling pathways. Mol. Endocrinol. 6, 272-278.

19. Lazari, M.F., Bertrand, J.E., Nakamura, K., Liu, X., Krupnick, J.G., Benovic, J.L. \& Ascoli, M. (1998) Mutation of individual serine residues in the $\mathrm{C}$-terminal tail of the lutropin/choriogonadotropin receptor reveal distinct structural requirements for agonist-induced uncoupling and agonist-induced internalization. J. Biol. Chem. 273, 18316-18324.

20. Hipkin, R.W., Sanchez-Yague, J. \& Ascoli, M. (1993) Agonistinduced phosphorylation of the luteinizing hormone/chorionic gonadotropin receptor expressed in a stably transfected cell line. Mol. Endocrinol. 7, 823-832.

21. Hipkin, R.W., Wang, Z. \& Ascoli, M. (1995) Human chorionic gonadotropin (CG) and phorbol ester-stimulated phosphorylation of the luteinizing hormone/CG receptor maps to serines 635, 639, 649, and 652 in the C-terminal cytoplasmic tail. Mol. Endocrinol. 9, 151-158.

22. Bradbury, F.A. \& Menon, K.M. (1999) Evidence that constitutively active luteinizing hormone/human chorionic gonadotropin receptors are rapidly internalized. Biochemistry 38, 8703-8712.

23. Liao, C.F., Schilling, W.P., Birnbaumer, M. \& Birnbaumer, L. (1990) Cellular responses to stimulation of the M5 muscarinic acetylcholine receptor as seen in murine L cells. J. Biol. Chem. 265, 11273-11284.

24. Berridge, M.J., Downes, C.P. \& Hanley, M.R. (1982) Lithium amplifies agonist-dependent phosphatidylinositol responses in brain and salivary glands. Biochem. J. 206, 587-595.

25. Dufau, M.L. (1998) The luteinizing hormone receptor, Annu. Rev. Physiol. 60, 461-496.

26. Nakamura, K. \& Ascoli, M. (1999) A dileucine-based motif in the C-terminal tail of the lutropin/choriogonadotropin receptor inhibits endocytosis of the agonist-receptor complex. Mol. Pharmacol. 56, 728-736.

27. Freedman, N.J., Liggett, S.B., Drachman, D.E., Pei, G., Caron, M.G. \& Lefkowitz, R.J. (1995) Phosphorylation and desensitization of the human beta 1-adrenergic receptor. Involvement of $\mathrm{G}$ protein-coupled receptor kinases and cAMP-dependent protein kinase. J. Biol. Chem. 270, 17953-17961.

28. Lohse, M.J., Benovic, J.L., Codina, J., Caron, M.G. \& Lefkowitz, R.J. (1990) beta-Arrestin: a protein that regulates beta-adrenergic receptor function. Science 248, $1547-1550$.

29. Sterne-Marr, R., Gurevich, V.V., Goldsmith, P., Bodine, R.C., Sanders, C., Donoso, L.A. \& Benovic, J.L. (1993) Polypeptide variants of beta-arrestin and arrestin3. J. Biol. Chem. 268, 15640-15648.

30. Attramadal, H., Arriza, J.L., Aoki, C., Dawson, T.M., Codina, J., Kwatra, M.M., Snyder, S.H., Caron, M.G. \& Lefkowitz, R.J. (1992) Beta-arrestin2, a novel member of the arrestin/beta-arrestin gene family. J. Biol. Chem. 267, 17882-17890.

31. Loisel, T.P., Adam, L., Hebert, T.E. \& Bouvier, M. (1996) Agonist stimulation increases the turnover rate of beta 2AR-bound palmitate and promotes receptor depalmitoylation. Biochemistry 35, 15923-15932.

32. Morello, J.P. \& Bouvier, M. (1996) Palmitoylation: a posttranslational modification that regulates signalling from G-protein coupled receptors. Biochem. Cell Biol. 74, 449-457.

33. Loisel, T.P., Ansanay, H., Adam, L., Marullo, S., Seifert, R., Lagace, M. \& Bouvier, M. (1999) Activation of the beta (2)-adrenergic receptor-Galpha (s) complex leads to rapid depalmitoylation and inhibition of repalmitoylation of both the receptor and Galpha (s). J. Biol. Chem. 274, 31014-31019.

34. Moffett, S., Adam, L., Bonin, H., Loisel, T.P., Bouvier, M. \& Mouillac, B. (1996) Palmitoylated cysteine 341 modulates phosphorylation of the beta2-adrenergic receptor by the cAMP-dependent protein kinase. J. Biol. Chem. 271, 21490-21497. 